\title{
PENGARUH KEBIJAKAN DIVIDEN, PROFITABILITAS, DAN PERTUMBUHAN ASET PERUSAHAAN TERHADAP NILAI PERUSAHAAN PADA INDUSTRI MANUFAKTUR DI BURSA EFEK INDONESIA
}

\author{
Muhammad Nurochman \\ Muh. Yunus Kasim \\ Vitayanti Fattah \\ Jurusan Manajemen Fakultas Ekonomi Universitas Tadulako \\ Email: omanzmuhammad@gmail.com
}

\begin{abstract}
The purpose of this study is to determine simultaneous and partial influence of dividend policy, profitability, and growth of corporate assets on the value of companies in the Manufacturing industry listed on the Indonesia Stock Exchange. This research is a quantitative descriptive. Sample consists of 11 companies in manufacturing industry listed on Indonesia Stock Exchange with research period of 5 years starting from 2012 until 2016. The study uses panel data regression with fixed effect model. The result shows that dividend policy, profitability, and growth of company asset simultaneously have significant influence on company value with $R$ square value of 0.9588 means that dividend policy, profitability, and growth of company asset is $95,88 \%$ and the rest of 4,12\% influenced by other variables that are not examined. Partially, dividend policy and growth of company asset have nonsignificant influence on company's value while profitability has significant influence.
\end{abstract}

Keywords: dividend policy, profitability, growth of company assets, and corporate valu

\section{ABSTRAK}

Tujuan penelitian ini adalah untuk mengetahui pengaruh variabel kebijakan dividen, profitabilitas, dan pertumbuhan aset perusahaan secara serempak dan parsial terhadap nilai perusahaan pada industri Manufaktur yang terdaftar di Bursa Efek Indonesia. Penelitian ini merupakan penelitian yang deksriptif yang bersifat kuantitatif. Sampel dalam penelitian ini sebanyak 11 perusahaan pada industri manufaktur yang terdaftar di Bursa Efek Indonesia dengan periode penelitian selama 5 tahun mulai tahun 2012 hingga 2016. Metode penelitian ini menggunakan regresi data panel dengan model fixed effect. Hasil Penelitian menunjukkan variabel kebijakan dividen, profitabilitas, dan pertumbuhan aset perusahaan secara serempak memiliki pengaruh yang signifikan terhadap nilai perusahaan dengan nilai R Squared sebesar 0.9588 artinya bahwa kebijakan dividen, profitabilitas, dan pertumbuhan aset perusahaan sebesar 95,88\% dan sisanya sebesar 4,12\% dipengaruhi oleh variabel lain yang tidak diteliti. Secara parsial variabel kebijakan dividen dan pertumbuhan aset perusahaan berpengaruh tetapi tidak signifikan terhadap nilai perusahaan sedangkan profitabilitas berpengaruh signifikan terhadap nilai perusahaan.

Kata kunci: Kebijakan Dividen, Profitabilitas, Pertumbuhan Aset Perusahaan, Nilai Perusahaan

\section{PENDAHULUAN}

Peranan sektor industri pada pertumbuhan perekonomian Indonesia amatlah penting. Salah satu sektor industri yang memegang peranan penting pada tumbuh dan kembangnya perekonomian Indonesia yakni sektor industri manufaktur. Industri manufaktur merupakan industri yang mendominasi perusahaan-perusahaan yang terdaftar di Bursa Efek Indonesia (BEI). Banyaknya perusahaan dalam industri, kondisi perekonomian saat ini telah menciptakan suatu pesaingan yang ketat antar perusahaan manufaktur. Persaingan dalam industri manufaktur membuat setiap perusahaan semakin meningkatkan kinerja agar tujuannya dapat tetap tercapai. Perkembangan sampai dengan akhir periode tahun 2016, tercatat 535 perusahaan yang mendaftarkan sahamnya (listing) di Bursa Efek Indonesia (BEI). Terdapat 144 perusahaan yang termasuk dalam sektor manufaktur (Bursa Efek Indonesia, 2016). Banyaknya jumlah perusahaan, jelas akan membuat investor dihadapkan pada 
banyak pilihan sulit dalam mengambil keputusan untuk berinvestasi. Menyikapi keadaan seperti ini, maka setiap investor harus lebih berhati-hati dalam menentukan keputusan investasinya. Hal ini dikarenakan apabila keputusan investasi tersebut kurang tepat, dimungkinkan investor tidak akan memperoleh return dan bahkan modal awal yang di investasikan akan hilang. Upaya untuk menghindari hal tersebut, setiap investor hendaknya mengumpulkan informasi yang mendetail mengenai perusahaan yang akan ditetapkan untuk berinvestasi. Perlu banyak pertimbangan yang harus diperhatikan jika seorang investor ingin membuat keputusan untuk menanamkan investasinya.

Nilai perusahaan dapat dilihat dari kemampuan perusahaan membayar dividen. Para investor memiliki tujuan utama untuk meningkatkan kesejahteraan dengan mengharapkan pengembalian dalam bentuk dividen maupun capital gain. Kebijakan dividen yang optimal ialah kebijakan dividen yang menciptakan keseimbangan antara dividen saat ini dan pertumbuhan dimasa mendatang sehingga memaksimumkan harga saham perusahaan (Brigham dan Houston, 2001:198).

Seorang investor yang tidak bersedia berspekulasi akan lebih memilih dividen daripada capital gain (Prihantoro, 2003). Besarnya dividen ini dapat mempengaruhi harga saham. Apabila dividen yang dibayar tinggi, maka harga saham cenderung tinggi sehingga nilai perusahaan juga tinggi. Sebaliknya bila jika dividen yang dibayarkan kecil maka harga saham perusahaan tersebut juga rendah. Kemampuan membayar dividen erat hubungannya dengan kemampuan perusahaan memperoleh laba. Jika perusahaan memperoleh laba yang besar, maka kemampuan membayar dividen juga besar. Oleh karena itu, dividen yang besar akan meningkatkan nilai perusahaan (Harjito dan Martono, 2005:3).

Profitabilitas merupakan suatu indikator kinerja yang dilakukan oleh manajemen perusahaan dalam mengelola kekayaan perusahaan yang ditunjukkan oleh laba yang dihasilkan perusahaan. Laba yang dihasilkan perusahaan berasal dari penjualan dan keputusan investasi yang dilakukan perusahaan. Salah satu ukuran kinerja perusahaan yang sering digunakan sebagai dasar pengambilan keputusan adalah laba yang dihasilkan oleh perusahaan (Subramanyam, 1996).

Pertumbuhan cepat juga memaksa sumber daya manusia yang dimiliki untuk secara optimal memberikan kontribusinya. Agar pertumbuhan cepat tidak memiliki arti pertumbuhan biaya yang kurang terkendali, maka dalam mengelola pertumbuhan, perusahaan harus memiliki pengendalian operasi dengan penekanan pada pengendalian biaya. Besarnya rata-rata nilai perusahaan, dividen, profitabilitas, dan pertumbuhan perusahaan pada perusahaan industri manufaktur yang terdaftar di BEI selama periode 2012-2016 dapat dilihat pada tabel sebagai berikut:

\section{Tabel 1}

Rata-rata tingkat nilai perusahaan, dividen, profitabilitas, dan pertumbuhan perusahaan pada Perusahaan Industri Manufaktur yang terdaftar di BEI periode 2012-2016 (Angka pada tabel disajikan dalam persentase)

\begin{tabular}{|c|c|c|c|c|c|c|}
\hline \multirow{2}{*}{ No. } & \multirow{2}{*}{ Variabel } & \multicolumn{5}{|c|}{ Tahun } \\
\cline { 3 - 7 } & & $\mathbf{2 0 1 2}$ & $\mathbf{2 0 1 3}$ & $\mathbf{2 0 1 4}$ & $\mathbf{2 0 1 5}$ & $\mathbf{2 0 1 6}$ \\
\hline 1. & Nilai Perusahaan (Tobin's Q) & 5,36 & 6,25 & 5,41 & 4,65 & 4,71 \\
\hline 2. & Dividen (DPR) & 49,85 & 62,31 & 48,78 & 41,58 & 59,24 \\
\hline 3. & Profitabilitas (ROA) & 21,26 & 24,71 & 18,55 & 16,42 & 17,20 \\
\hline 4. & Pertumbuhan Perusahaan (GROWTH) & 16,32 & 18,15 & 17,95 & 8,49 & 10,42 \\
\hline
\end{tabular}

Sumber: idx.co.id 2012-2016. (Data diolah).

Tabel 1 dapat dilihat bahwa rata-rata dari variabel nilai perusahaan, kebijakan dividen, profitabilitas, dan pertumbuhan perusahaan menunjukkan hasil yang fluktuatif. Fenomena empiris dalam penelitian ini didasarkan pada inkonsistensi data. Misalnya, pada variabel dividen tahun 2012 nilai rata-ratanya sebesar 49,85 \%, mengalami kenaikan menjadi $62,31 \%$ di tahun 2013 . Hal tersebut selaras dengan nilai rata-rata pada variabel nilai perusahaan tahun 2012 sebesar 5,36 \%, dan mengalami peningkatan pada tahun 2013 yaitu sebesar 6,25\%. Hal ini berarti sejalan dengan teori 
yang ada, bahwa semakin tinggi tingkat dividen yang dibagikan akan meningkat pula nilai dari suatu perusahaan tersebut ataupun sebaliknya.

Fenomena serupa terjadi pada variabel lainnya yang diduga berpengaruh terhadap nilai perusahaan. Berdasarkan data pada tabel 1 , tidak terlihat kejelasan tentang pengaruh dividen, profitabilitas, dan pertumbuhan perusahaan terhadap nilai perusahaan. Berdasarkan uraian maka perlu menganalisis masalah yang terjadi.

\section{KAJIAN LITERATUR DAN PENGEMBANGAN HIPOTESIS}

\section{Nilai Perusahaan}

Memaksimalkan nilai perusahaan sangat penting artinya bagi suatu perusahaan, karena dengan memaksimalkan nilai perusahaan berarti juga memaksimalkan kemakmuran pemegang saham yang merupakan tujuan utama perusahaan (Euis dan Taswan, 2002). Semakin tinggi harga saham semakin tinggi pula nilai perusahaan. Nilai perusahaan yang tinggi akan membuat pasar percaya tidak hanya pada kinerja perusahaan saat ini namun juga pada prospek perusahaan di masa depan. Sedangkan menurut (Keown, 2004) nilai perusahaan merupakan nilai pasar atas surat berharga hutang dan ekuitas perusahaan yang beredar.

Rasio-rasio keuangan digunakan investor untuk mengetahui nilai pasar perusahaan. Rasio tersebut dapat memberikan indikasi bagi manajemen mengenai penilaian investor terhadap kinerja perusahaan dimasa lampau dan prospeknya dimasa depan. Ada beberapa rasio untuk mengukur nilai pasar perusahaan, salah satunya Tobin's Q. Rasio ini dinilai bisa memberikan informasi paling baik, karena rasio ini bisa menjelaskan berbagai fenomena dalam kegiatan perusahaan, seperti misalnya terjadinya perbedaan cross-sectional dalam pengambilan keputusan investasi dan diversifikasi (Claessens dan Fan, 2003). Tobin's Q ditemukan oleh seorang pemenang hadiah nobel dari Amerika Serikat yaitu James Tobin. Tobin Q dapat dirumuskan sebagai perbandingan nilai pasar aset dengan perkiraan jumlah uang yang harus dikeluarkan untuk mengganti seluruh aset tersebut pada saat ini, sehingga dapat dituliskan sebagai berikut:

$$
\text { Tobin's } Q=\frac{\text { Market Value of Assets }}{\text { Estimated Replacement Cost }}
$$

\section{Kebijakan Dividen}

Kebijakan dividen menyangkut tentang keputusan untuk membagikan laba yang diperoleh perusahaan kepada pemegang saham dalam bentuk dividen atau laba ditahan guna pembelanjaan investasi di masa mendatang. Kebijakan dividen merupakan keputusan pembayaran dividen yang mempertimbangkan maksimalisasi harga saham saat ini dan periode mendatang. Penentuan besar kecilnya dividen yang akan dibayarkan pada perusahaan yang sudah merencanakan dengan menetapkan target Dividend Payout Ratio didasarkan atas perhitungan keuntungan yang diperoleh setelah dikurangi pajak. Untuk dapat membayar dividen dapat dibuat suatu rencana pembayarannya (Silvia, 2013). DPR (Dividen Payout Ratio) merupakan perbandingan antara (DPS) dividen per lembar saham dengan (EPS) laba per lembar saham (Ang, 2007: 6).

$$
\boldsymbol{D P R}=\frac{\text { Dividen Perlembar Saham }}{\text { Laba Perlembar Saham }}
$$

\section{Profitabilitas}

Profitabilitas adalah hasil akhir dari sejumlah kebijakan dan keputusan manajemen perusahaan (Brigham dan Gapenski, 1996). Profitabilitas perusahaan merupakan kemampuan perusahaan dalam menghasilkan laba bersih dari aktivitas yang dilakukan pada periode akuntansi. Rasio profitabilitas yang digunakan dalam penelitian ini yaitu return on assets (ROA). Return On Asset adalah 
salah satu rasio profitabilitas yang dimaksudkan untuk mengukur kemampuan perusahaan atas keseluruhan dana yang ditanamkan dalam aktivitas yang digunakan untuk aktivitas operasi perusahaan dengan tujuan menghasilkan laba dengan memanfaatkan aktiva yang dimilikinya. Return On Asset diperoleh dengan cara membandingkan net income terhadap total asset. Formula yang digunakan untuk menghitung Return On Assets (ROA) yakni sebagai berikut (Horne, 2005:225) :

$$
R O A=\frac{\text { Laba Bersih Setelah Pajak }}{\text { Total Aktiva }} \times 100
$$

\section{Pertumbuhan Aset Perusahaan}

Pertumbuhan perusahaan adalah salah satu tujuan yang sangat diharapkan oleh pihak internal maupun eksternal suatu perusahaan karena memberikan suatu dampak yang baik bagi perusahaan maupun pihak-pihak yang berkepentingan terhadap perusahaan yaitu investor, kreditur dan pemegang saham. Pertumbuhan perusahaan merupakan dampak dari arus dana perusahaan dari perubahan operasional yang disebabkan oleh pertumbuhan atau penurunan volume usaha (Helfert, 1997). Pertumbuhan asset perusahaan dihitung dengan rumus sebagai berikut (Badhuri, 2002):

$$
\text { GROWTH }=\frac{\text { Total Asset } \mathrm{t}-\text { Total Asset } \mathrm{o}}{\text { Total Asset } \mathrm{o}} \times 100
$$

\section{Pengaruh Kebijakan Dividen Terhadap Nilai Perusahaan}

Kebijakan dividen yang optimal ialah kebijakan dividen yang menciptakan keseimbangan antara dividen saat ini dan pertumbuhan di masa mendatang sehingga memaksimumkan harga saham perusahaan (Brigham dan Houston, 2001: 198). Apabila perusahaan meningkatkan pembayaran dividen, mungkin diartikan oleh pemodal sebagai sinyal harapan manajemen tentang akan membaiknya kinerja perusahaan di masa yang akan datang. Sehingga pembayaran dividen memiliki pengaruh terhadap nilai perusahaan. Perusahaan yang menurunkan pembayaran dividen akan mempunyai laba ditahan yang besar, laba ditahan tersebut yang akan digunakan sebagai modal perusahaan untuk meningkatkan perusahaan tersebut yang kemudian akan meningkatkan laba dan nilai perusahaan akan meningkat.

\section{Pengaruh Profitabilitas Terhadap Nilai Perusahaan}

Profitabilitas adalah kemampuan perusahaan dalam memperoleh laba (Saidi, 2004). Laba merupakan tingkat keuntungan bersih yang mampu diraih oleh perusahan pada saat menjalankan operasinya. Laba yang layak dibagikan kepada pemegang saham adalah laba setelah bunga dan pajak. Salah satu evaluasi kinerja yang sering digunakan oleh banyak stakeholder adalah melalui rasio profitabilitas. Hal tersebut dapat dilihat melalui return dari aset yang telah diinvestasikan maupun dari penanaman modal oleh stakeholder (Brigham et al, 2001). Pertumbuhan penjualan bersih yang dihasilkan oleh perusahaan juga akan menghasilkan profit yang lebih tinggi sehingga profit margin on sales dapat menjadi ukuran atas hasil yang telah dicapai oleh suatu perusahaan pada suatu periode.

\section{Pengaruh Pertumbuhan Aset Perusahaan Terhadap Nilai Perusahaan}

Pertumbuhan merupakan kemampuan perusahaan untuk mempertahankan posisi usahanya dalam perkembangan ekonomi dan industri di dalam perekonomian dimana perusahaan tersebut beroperasi (Rosma Pakpahan, 2010). Asset merupakan aktiva yang digunakan untuk aktivitas operasional perusahaan. Semakin besar asset maka diharapkan semakin besar pula hasil operasional yang akan dihasilkan. Pertumbuhan yang tinggi menyebabkan kebutuhan dana meningkat (kecenderungannya pada laba ditahan). Semakin besar tingkat pertumbuhan perusahaan, maka semakin tinggi biaya yang 
diperlukan untuk investasi. Perusahaan yang bertumbuh akan membutuhkan dana yang lebih besar dibandingkan perusahaan yang lebih mapan. Peningkatan asset akan diikuti dengan peningkatan hasil operasional. Hal ini akan meningkatkan kepercayaan para investor.

\section{Hipotesis}

1. Kebijakan Dividen, profitabilitas, dan pertumbuhan aset perusahaan secara serempak berpengaruh (+) dan signifikan terhadap nilai perusahaan pada Industri Manufaktur di Bursa Efek Indonesia.

2. Kebijakan Dividen secara parsial berpengaruh (-) dan signifikan terhadap nilai perusahaan pada Industri Manufaktur di Bursa Efek Indonesia.

3. Profitabilitas secara parsial berpengaruh (+) dan signifikan terhadap nilai perusahaan pada Industri Manufaktur di Bursa Efek Indonesia.

4. Pertumbuhan aset perusahaan secara parsial berpengaruh (+) dan signifikan terhadap nilai perusahaan pada Industri Manufaktur di Bursa Efek Indonesia.

\section{METODE PENELITIAN}

Jenis penelitian ini jika dikategorikan berdasarkan temuan adalah penelitian jenis applied research. Menurut Tri Wahyuni (2013) applied research yaitu penelitian untuk mengembangkan penelitian yang telah dilakukan sebelumnya. Penelitian ini merupakan penelitian yang menggunakan pendekatan kuantitatif, yaitu penelitian yang melibatkan data-data kuantitatif di dalam pembuktian teori, sedangkan jika diklasifikasikan berdasarkan tujuan, penelitian ini bersifat kausal, yaitu penelitian yang dilakukan untuk mengetahui apakah variabel bebas yang terdiri dari kebijakan dividen, profitabilitas, dan pertumbuhan perusahaan memiliki pengaruh terhadap variabel terikat, yaitu nilai perusahaan.

Jenis data dalam penelitian ini adalah data panel yang merupakan gabungan antara time series (periode penelitian) dengan cross section (perusahaan). Data yang digunakan adalah data laporan keuangan perusahaan sektor Manufaktur di Bursa Efek (BEI) Indonesia periode 2012-2016.

Menurut Sugiyono (2014:148), populasi merupakan wilayah generalisasi yang terdiri atas: obyek/subyek yang mempunyai kuantitas dan karakteristik tertentu yang ditetapkan oeh peneliti untuk dipelajari dan kemudian ditarik kesimpulannya. Populasi dalam penelitian ini adalah perusahaan yang telah go public dan sahamnya tercatat di BEI yang termasuk dalam sektor Industri Manufaktur periode 2012-2016 yaitu sebanyak 144 perusahaan. Sampel menurut Sugiyono (2011:81) adalah bagian dari jumlah dan karakteristik yang dimiliki oleh populasi tersebut. Pemilihan sampel penelitian ini ditentukan secara purposive sampling, yaitu sampel ditarik sejumlah tertentu dari populasi emiten dengan menggunakan pertimbangan atau kriteria tertentu. Pertimbangantersebut adalah:

1. Merupakan perusahaan manufaktur yang tercatat di Bursa Efek Indonesia selama periode 20122016, jika perusahaan baru terdaftar pada tahun tersebut atau delisting pada tahun tersebut maka perusahaan tidak dapat dijadikan sampel.

2. Perusahaan yang mempublikasikan laporan keuangan periodik selama periode pengamatan dari tahun 2012 hingga tahun 2016 dengan lengkap.

3. Perusahaan manufaktur yang membagikan dividen selama lima tahun berturut-turut yaitu pada tahun 2012 sampai dengan tahun 2016.

Berdasarkan data perusahaan yang terdaftar di BEI pada sektor industri manufaktur diketahui bahwa perusahaan yang terdaftar pada tahun 2012-2016 total ada 144 perusahaan. Jumlah tersebut hanya 11 sampel perusahaan selama 5 tahun yang memenuhi kriteria sampel penelitian.

Teknik pengumpulan data dengan dokumentasi. Metode dokumentasi menurut Arikunto (2006:231) yaitu mencari data-data mengenai hal-hal atau variabel yang berupa catatan, transkip, buku, surat kabar, majalah, prasasti, notulen rapat, lengger, agenda dan sebagainya. Untuk memperoleh hasil penelitian yang diharapkan, dibutuhkan data dan informasi yang mendukung penelitian ini. Data atau dokumen yang digunakan dalam penelitian ini adalah Laporan Keuangan 
Nurochman, M.

perusahaan manufaktur yang terdapat pada Indonesian Capital Market Directory yang berisi ringkasan laporan keuangan perusahaan manufaktur yang terdaftar di bursa Efek Indonesia periode 2012-2016.

\section{Teknis Analisis Data}

Analisis Perhitungan Kebijakan Dividen, Profitabilitas, Pertumbuhan Aset Perusahaan, dan Nilai Perusahaan

Rumus perhitungan kebijakan dividen adalah sebagai berikut (Ang, 2007 : 6):

$$
\text { Kebijakan Dividen }=\frac{\mathrm{DPS}}{\mathrm{EPS}} \times 100
$$

Rumus perhitungan profitabilitas adalah (Horne, 2005:225):

$$
\text { Profitabilitas }=\frac{\text { Laba Bersih Setelah Pajak }}{\text { Total Aktiva }}
$$

Rumus perhitungan pertumbuhan aset perusahaan adalah (Badhuri, 2002):

$$
\text { Pertumbuhan Asset }=\frac{\text { Total Asset-Total Asset } 0}{\text { Total Asset } 0}
$$

Rumus perhitungan nilai perusahaan adalah (Klapper dan Love, 2012:35) adalah:

$$
\text { Nilai Perusahaan }=\frac{\mathrm{ME}+\mathrm{DEBT}}{\mathrm{TA}}
$$

\section{Analisis Data Panel}

Metode yang digunakan dalam penelitian ini adalah uji regresi data panel. Data panel merupakan gabungan antara time series dengan cross section. Time Series merupakan jumlah periode yang digunakan dalam penelitian, sedangkan cross section merupakan jumlah dari sampel perusahaan yang akan diteliti.

Rumus regresi data panel :

$$
\text { TQit = b0 + b1DPRit + b2ROAit + b3GROWTHit }+ \text { eit }
$$

Keterangan:

$\begin{array}{ll}\text { TQ } & \text { : Nilai Perusahaan } \\ \text { b0 } & \text { : Konstanta } \\ \text { DPR } & \text { : Dividend Payout Ratio } \\ \text { ROA } & \text { : Return On Asset } \\ \text { GROWTH } & : \text { Growth } \\ \text { b1-b3 } & : \text { Koefisien regresi masing-masing variabel independen } \\ \text { t } & : \text { waktu } \\ \text { i } & : \text { perusahaan } \\ \varepsilon & : \text { error term }\end{array}$

\section{Uji Hipotesis}

\section{Uji F (Serempak)}

Uji F dilakukan untuk menguji signifikan pengaruh kebijakan dividen, profitabilitas, dan pertumbuhan aset perusahaan terhadap nilai perusahaan secara serempak. Uji F digunakan untuk 
mengetahui adanya pengaruh secara bersama-sama antara variabel bebas terhadap variabel terikat. Adapun kaidah pengambilan keputusan dari pengujian ini adalah:

(1) Jika F hitung $>\mathrm{F}$ tabel pada $\alpha=0,05$, atau tingkat kepercayaan $95 \%$, maka terbukti bahwa variabel independen $(\mathrm{X})$ secara serempak berpengaruh signifikan terhadap variabel dependen (Y) sehingga hipotesis yang diajukan dapat diterima kebenarannya.

(2) Jika $\mathrm{F}$ hitung $<\mathrm{F}$ tabel pada $\alpha=0,05$, atau tingkat kepercayaan $95 \%$, maka terbukti bahwa variabel independen $(\mathrm{X})$ secara serempak berpengaruh tidak signifikan terhadap variabel dependen $(\mathrm{Y})$ sehingga hipotesis yang diajukan tidak dapat diterima kebenarannya.

2. Uji t (Parsial)

Uji hipotesis penelitian ini menggunakan uji t (uji parsial) adalah pengujian hipotesis yang digunakan untuk menentukan pengaruh dari masing-masing variabel independen dengan variabel dependen. Oleh karena itu, kaidah pengambilan keputusan dari pengujian ini adalah sebagai berikut:

(1) Jika t hitung $>\mathrm{t}$ tabel pada $\alpha=0,05$, atau tingkat kepercayaan $95 \%$, maka terbukti bahwa variabel independen $(\mathrm{X})$ secara parsial berpengaruh signifikan terhadap variabel dependen (Y) sehingga hipotesis yang diajukan dapat diterima kebenarannya.

(2) Jika t hitung $<$ t tabel pada $\alpha=0,05$, atau tingkat kepercayaan $95 \%$, maka terbukti bahwa variabel independen $(\mathrm{X})$ secara parsial berpengaruh tidak signifikan terhadap variabel dependen $(\mathrm{Y})$ sehingga hipotesis yang diajukan tidak dapat diterima kebenarannya.

\section{Koefisien Determinasi}

Nilai koefisien determinasi mencerminkan seberapa besar variasi dari variabel dependen dapat dijelaskan oleh variabel independen. Penelitian ini, penulis menggunakan Adjusted $\mathrm{R}^{2}$ untuk mengukur koefisien determinasi dikarenakan nilainya lebih tepat (Nachrowi dan Usman, 2006).

\section{HASIL DAN PEMBAHASAN \\ HASIL PENELITIAN}

\section{Perkembangan Kebijakan Dividen}

Kebijakan dividen merupakan bagian yang menyatu dengan keputusan pendanaan perusahaan. Rasio pembayaran dividen (Dividen Payout Ratio) menentukan jumlah laba yang dapat ditahan sebagai sumber pendanaan. Semakin besar laba ditahan semakin sedikit jumlah laba yang dialokasikan untuk pembayaran dividen. Kebijakan keuangan ini merupakan keputusan yang penting, karena dapat berpengaruh terhadap nilai perusahaan. Kebijakan dividen yang tepat dapat berimplikasi terhadap kekayaan para pemegang saham perusahaan.

Rata-rata tingkat Dividen Payout Ratio pada perusahaan sampel selama periode 2012-2016 mengalami fluktuatif setiap tahunnya, yang mengartikan ditahun ini bisa saja naik dan di tahun depan bisa saja mengalami penurunan. Rata-rata tingkat Dividen Payout Ratio pada perusahaan sampel berkisar antara $41 \%$ hingga 62\%. Rata-rata Dividen Payout Ratio terendah sebesar $41 \%$ pada tahun 2015 disebabkan oleh adanya beberapa perusahaan sampel yang lebih memilih untuk menahan laba perusahaannya dibandingkan membagikan labanya dalam bentuk dividen, salah satunya yaitu PT. Multi Bintang Indonesia,Tbk yang hanya membagikan dividen sebanyak 2\% dari keseluruhan laba perusahaan. Sedangkan rata-rata Dividen Payout Ratio tertinggi sebesar 62\% pada tahun 2013 disebabkan oleh adanya beberapa perusahaan yang membagikan keseluruhan laba perusahaan dalam bentuk dividen yaitu, PT. Handjaya Mandala Sampoerna,Tbk, PT. Multi Bintang Indonesia,Tbk, dan PT. Unilever Indonesia,Tbk.

\section{Perkembangan Profitabilitas}

Profitabilitas adalah kemampuan perusahaan dalam meghasilkan laba melalui operasionalnya. ratarata tingkat profitabilitas dari 11 perusahaan sampel cenderung menurun, dimana pada tahun 2012 tingkat profitabilitas adalah sebesar $21 \%$ yang pada tahun 2016 menjadi 17\%, meskipun sempat 
mengalami kenaikan pada tahun 2013 sebesar 24\%. Hal tersebut disebabkan oleh inefisiensi aset yang ada pada perusahaan. Perusahaan belum mampu menghasilkan laba yang optimal dikarenakan terlalu banyak aset yang tidak produktif, misalnya cadangan kas yang terlalu tinggi, terlalu banyak penjualan dalam bentuk kredit, dan banyaknya mesin dan bangunan yang menganggur atau beroperasi di bawah kapasitas optimalnya.

Selama periode penelitian, PT Unilever Indonesia,Tbk adalah perusahaan dengan tingkat rata-rata tertinggi, bahkan pada tahun 2013 kemampuan perusahaan dalam menghasilkan keuntungan dengan menggunakan harta yang dimiliki adalah sebesar $71 \%$. Artinya bahwa, perusahaan mampu menghasilkan Rp.0.71 laba bersih, untuk setiap 1 rupiah harta yang dimiliki. Hal tersebut disebabkan oleh efisiensi aset yang dilakukan PT Unilever Indonesia,Tbk diantaranya menjual aset-aset yang tidak produktif sehingga total aset menjadi rendah.

\section{Perkembangan Pertumbuhan Aset Perusahaan}

Pertumbuhan suatu perusahaan merupakan tanda bahwa perusahaan memiliki aspek yang menguntungkan, dan para investor mengharapkan rate of return (tingkat pengembalian) dari investasi mereka memberikan hasil yang lebih baik. Tingkat rata-rata perbandingan total aktiva tahun berjalan terhadap total aktiva tahun sebelumnya mengalami fluktuatif. Bahkan pada tahun 2015, tingkat ratarata growth mengalami penurunan yang signifikan dibandingkan tahun-tahun sebelumnya, yakni secara keseluruhan perusahaan sampel rata-rata hanya mampu tumbuh sebesar $8 \%$ pada aset/harta yang dimiliki perusahaan. Hal tersebut disebabkan oleh adanya beberapa perusahaan yang sampai menyentuh angka negatif pada periode tersebut, yakni diantaranya PT Astra Otoparts,Tbk, PT Indocement Tunggal Prakarsa,Tbk, dan PT Multi Bintang Indonesia,Tbk. Akan tetapi menurunnya pertumbuhan aset tidak mencerminkan bahwa perusahaan tersebut dalam kondisi yang tidak baik, melainkan perusahaan tersebut melakukan efisiensi aset. Artinya, perusahaan tersebut menjual sebagian aset-aset yang tidak produktif. Aset-aset tidak produktif ini dapat dikategorikan sebagai aset yang menganggur.

Tingkat rata-rata growth tertinggi dicapai dua tahun berturut-turut pada tahun 2013 dan 2014. Hal tersebut disebabkan oleh adanya perusahaan yang mampu mengalami pertumbuhan yang signifikan dibandingkan periode sebelumnya, salah satunya adalah PT Multi Bintang Indonesia,Tbk. Hal tersebut disebabkan oleh cadangan kas yang terlalu tinggi, terlalu banyaknya penjualan dalam bentuk kredit, serta banyaknya mesin dan bangunan yang menganggur atau beroperasi dibawah kapasitas optimal.

\section{Perkembangan Nilai Perusahaan}

Nilai perusahaan mencerminkan prospek perusahaan dimasa yang akan datang. Semakin tinggi nilai perusahaan maka semakin baik pula kepercayaan investor tentang keberhasilan perusahaan. Penelitian ini, nilai perusahaan diukur dengan menggunakan Tobin's $Q$, yaitu perbandingan nilai pasar dengan nilai aset perusahaan yang tercatat.

Rata-rata nilai perusahaan periode 2012-2016 cenderung mengalami penurunan meskipun pada periode tahun 2013 sempat mengalami kenaikan. Tingkat rata-rata nilai perusahaan terendah sebesar 4,64. Meskipun tingkat rata-rata nilai perusahaan terendah, sesuai dengan kriteria penilaian tobin's $q$, jika nilai tersebut lebih besar dari 1, maka perusahaan memiliki prospek pertumbuhan yang baik. Artinya bahwa nilai pasar aset perusahaan 4,64 kali dibandingkan dengan nilai buku aset perusahaan. Sedangkan tingkat rata-rata nilai perusahaan tertinggi sebesar 6,16 pada tahun 2013. Hal tersebut disebabkan oleh PT Unilever Indonesia, Tbk yang nilai perusahaannya mencapai 27,21.

\section{Hasil Analisis Regresi Data Panel}

Guna membuktikan hipotesis yang dikemukakan dalam penelitian ini menggunakan alat analisis regresi data panel mengukur pengaruh Kinerja Keuangan terhadap Nilai Perusahaan pada perusahaan Industri Manufaktur di Bursa Efek Indonesia. Hasil perhitungan regresi data panel dari penelitian ini untuk hipotesis pertama dan kedua dapat dilihat pada tabel berikut ini: 
Tabel 2 Hasil Perhitungan

\begin{tabular}{|c|l|c|c|c|}
\hline $\begin{array}{c}\text { Variabel } \\
\text { Dependen (Y) }\end{array}$ & \multicolumn{1}{|c|}{ Variabel Independen (X) } & Koefisien & t hitung & Sig. \\
\hline \multirow{2}{*}{$\begin{array}{c}\text { Nilai } \\
\text { Perusahaan }\end{array}$} & Dividen Payout Ratio (DPR) & -0.000715 & -0.170143 & $0.8657>0.05$ \\
\cline { 2 - 5 } & Return On Asset (ROA) & 0.133657 & 5.841836 & $0.0000<0.05$ \\
\cline { 2 - 5 } & Growth & -0.008317 & -1.333600 & $0.1897>0.05$ \\
\hline Constanta & $\mathbf{2 . 7 9 7 2 4 0}$ & F Hitung & $\mathbf{7 3 . 5 6 0 8 3}$ \\
\hline R-Squared & 0.958889 & F Tabel & $\mathbf{2 . 7 8 6 2 2 9}$ \\
\hline Adjusted R-Squared & 0.945853 & Sig & $\mathbf{0 . 0 0 0 0 0 0}$ \\
\hline \multicolumn{2}{|l|}{} & t Tabel & $\mathbf{2 . 0 0 7 5 8 4}$ \\
\hline
\end{tabular}

Sumber: Hasil output regresi panel data eviews 6

$\mathrm{TQ}=2.797240+(-0.000715($ DPR $))+(\mathbf{0 . 1 3 3 6 5 7}($ ROA $))+(-0.008317($ GROWTH $))+\mathrm{e}$

Variabel Dividen Payout Ratio $\left(\mathrm{X}_{1}\right)$ mempunyai koefisien sebesar $(-0,000715)$, hal ini berarti setiap perubahan (penurunan) variabel $\mathrm{X}_{1}$ sebesar 1 persen, maka nilai perusahaan akan menurun sebesar 0,000715. Variabel Return On Asset $\left(\mathrm{X}_{2}\right)$ mempunyai koefisien sebesar 0.133657, hal ini berarti setiap perubahan variabel $\mathrm{X}_{2}$ sebesar 1 persen, nilai perusahaan akan menurun sebesar 0.133657. Variabel Growth (X3) mempunyai koefisien sebesar -0.008317 , hal ini berarti setiap perubahan variabel $\mathrm{X}_{3}$ sebesar 1 persen, nilai perusahaan akan menurun sebesar -0.008317 .

\section{Hasil Pengujian Hipotesis Secara Serempak}

Kriteria pengujian hipotesis yang pertama dalam penelitian ini adalah dengan membandingkan $F_{\text {hitung }}(\mathbf{7 3 , 5 6 0 8 3})>F_{\text {tabel }}(\mathbf{2 . 7 8 6 2 2 9})$ dengan taraf signifikan $(\mathbf{0 , 0 0 0}<\mathbf{0 , 0 5})$ maka kesimpulannya $\mathrm{H}_{0}$ ditolak dan $\mathrm{H}_{1}$ diterima. Dapat diartikan bahwa seluruh variabel independen yaitu Dividen Payout Ratio, Return On Asset, dan Growth yang dimasukkan dalam model secara simultan atau serempak berpengaruh signifikan terhadap variabel dependen yaitu Nilai perusahaan. Maka dari pernyataan diatas disimpulkan bahwa dalam penelitian ini hipotesis pertama yang menyatakan bahwa Kinerja Keuangan (DPR, ROA, GROWTH) secara bersama-sama berpengaruh signifikan terhadap Nilai Perusahaan Industri Manufaktur yang terdaftar di Bursa Efek Indonesia.

\section{Hasil Pengujian Hipotesis Secara Parsial}

1. Variabel Kebijakan Dividen $\left(\mathrm{X}_{1}\right)$

Pengujian tentang berpengaruh atau tidaknya variabel Dividen Payout Ratio terhadap Nilai Perusahaan adalah dengan melihat taraf signifikansi $(0.8657>0,05)$ dan nilai koefisien -0.000715 . Taraf signifikansi memberikan makna bahwa Dividen Payout Ratio tidak berpengaruh signifikan terhadap nilai perusahaan. Maka dari pernyataan diatas disimpulkan bahwa hipotesis kedua tidak sesuai dengan hipotesis yang menyatakan variabel Kebijakan Dividen secara parsial berpengaruh positif dan signifikan terhadap Nilai Perusahaan Industri Manufaktur yang terdaftar di Bursa Efek Indonesia periode 2012-2016. Kemudian perlakuan atas uji arah untuk menentukan apakah hubungan antara kedua variabel merupakan hubungan yang positif atau negatif dengan melihat koefisiennya. Tidak adanya hubungan antara kedua variabel maka analisis mengenai uji arah tidak diperlukan lagi.

2. Variabel Profitabilitas $\left(\mathrm{X}_{2}\right)$

Pengujian tentang berpengaruh atau tidaknya variabel Return On Asset terhadap nilai perusahaan adalah dengan melihat taraf signifikansi $(0.0000<0,05)$ dan nilai koefisien 0.133657 . Taraf signifikansi memberikan makna bahwa Return On Asset berpengaruh secara signifikan terhadap nilai perusahaan yang terlihat dari nilai probability sebesar 0,00 yang berada di bawah 0,05 . Maka dari pernyataan diatas disimpulkan bahwa hipotesis ketiga sesuai dengan hipotesis yang menyatakan 
Nurochman, M.

variabel Profitabilitas secara parsial berpengaruh positif dan signifikan terhadap nilai perusahaan Industri Manufaktur di Bursa Efek Indonesia periode 2012-2016.

3. Pertumbuhan Aset Perusahaan $\left(\mathrm{X}_{3}\right)$

Pengujian tentang berpengaruh atau tidaknya variabel Growth terhadap nilai perusahaan adalah dengan melihat taraf signifikansi $(0.1897>0,05)$ dan nilai koefisien 0.009687 . Taraf signifikansi memberikan makna bahwa Growth tidak berpengaruh signifikan terhadap nilai perusahaan yang terlihat dari nilai probability sebesar 0,1897. Maka dari pernyataan diatas disimpulkan bahwa hipotesis keempat tidak sesuai dengan hipotesis yang menyatakan variabel Pertumbuhan Perusahaan secara parsial berpengaruh signifikan terhadap nilai perusahaan Industri Manufaktur di Bursa Efek Indonesia periode 2012-2016.

\section{Hasil Pengujian Koefisien Determinasi}

Hasil perhitungan yang diperoleh besarnya koefisien determinasi yang disesuaikan ( $R$ Squared) adalah 0.958889. Artinya pengaruh semua variabel independen (DPR, ROA, GROWTH) terhadap perubahan nilai variabel dependen adalah sebesar 95\% dan sisannya 5\% dipengaruhi oleh variabel lain selain variabel independen yang digunakan dalam regresi data panel seperti manajemen perusahaan, faktor eksternal perusahaan antara lain peraturan pemerintah, tingkat suku bunga, inflasi, nilai tukar rupiah dan kondisi perekonomian yang tidak stabil.

\section{PEMBAHASAN}

\section{Pengaruh Variabel Kinerja Keuangan Perusahaan Perusahaan Terhadap Nilai Perusahaan}

Berdasarkan penelitian yang dilakukan kinerja keuangan perusahaan mempunyai pengaruh signifikan terhadap nilai perusahaan. Hal ini sejalan dengan Siqnaling Theory yang menjelaskan alasan perusahaan memberikan informasi laporan keuangan pada pihak eksternal karena terdapat asimetri informasi antara perusahaan dan pihak luar sedangkan informasi di dalam perusahaan merupakan sinyal bagi pelaku pasar untuk melakukan investasi dan mempengaruhi prospek perusahaan di masa depan, dan sesuai dengan yang diungkapkan oleh Wolk., (2000) tentang salah satu cara untuk mengurangi informasi asimetri adalah dengan memberikan sinyal pada pihak luar, salah satunya berupa informasi keuangan yang dapat dipercaya dan akan mengurangi ketidakpastian mengenai prospek perusahaan yang akan datang. Laporan keuangan sangat membantu para investor untuk menilai dan mengukur keadaan perusahaan saat ini dan akan datang. Melihat laporan keuangan tahun sebelumnya hingga laporan keuangan terbaru yang dikeluarkan perusahaan, investor akan lebih mudah mengetahui prospek perusahaan dimasa yang akan datang. Oleh karena itu, ketika rasio-rasio perusahaan menunjukkan nilai yang baik dan sesuai dengan harapan investor dan secara tidak langsung akan meningkatkan nilai perusahaan itu sendiri.

\section{Pengaruh Variabel Kebijakan Dividen Terhadap Nilai Perusahaan}

Awalnya peneliti beranggapan bahwa dividen payout ratio akan berpengaruh positif terhadap nilai perusahaan, namun hal ini tidak sesuai dengan hasil penelitian yang didapatkan. Hasil penelitian menunjukkan bahwa DPR tidak berpengaruh signifikan terhadap Nilai perusahaan. Hal ini bisa terjadi dikarenakan besar kecilnya dividen yang dibagikan kepada para pemegang saham, tidak berkaitan dengan tinggi rendahnya nilai perusahaan. Besar kecilnya dividen yang dibagikan perusahaan kepada para pemegang saham tidak menjadi pertimbangan rasional investor dalam berinvestasi di saham. Meskipun dividen yang dibagikan oleh perusahaan hanya kecil tetapi nilai perusahaannya tetap meningkat.

\section{Pengaruh Variabel Profitabilitas Terhadap Nilai Perusahaan}

Variabel Return On Asset memiliki pengaruh positif dan signifikan terhadap nilai perusahaan. Nilai signifikansi berada dibawah 0,05 yakni sebesar 0,00 atau $0,00<0,05$ dengan rata-rata return on asset selama 5 tahun berkisar antara 16,41 hingga 21,63. Angka tersebut menurut peneliti merupakan nilai 
yang sehat untuk mengukur tingkat profitabilitas dari perusahaan manufaktur. Kondisi ini terjadi karena salah satu evaluasi kinerja yang sering digunakan oleh banyak stakeholder adalah melalui rasio profitabilitas. Hal tersebut dapat dilhat dari aset yang telah diinvestasikan maupun penanaman modal oleh shareholder. Selain itu profitabilitas yang tinggi menunjukkan prospek perusahaan yang baik, sehingga investor akan merespon positif sinyal tersebut dan nilai perusahaan akan meningkat. Investor menanamkan modal saham pada sebuah perusahaan dengan tujuan untuk mendapatkan return, sedangkan return saham akan meningkat jika nilai perusahaan di mata investor adalah baik, yang ditandai dengan kinerja perusahaan yang baik (profitabilitas yang meningkat).

\section{Pengaruh Variabel Pertumbuhan Aset Perusahaan Terhadap Nilai Perusahaan}

Awalnya peneliti beranggapan bahwa growth akan berpengaruh positif terhadap nilai perusahaan, namun hal ini tidak sesuai dengan hasil penelitian yang didapatkan. Hasil penelitian menunjukkan bahwa Growth tidak berpengaruh signifikan terhadap Nilai Perusahaan. Hal ini bisa terjadi dikarenakan adanya peningkatan pada beban operasional perusahaan, sehingga laba yang dihasilkan akan berkurang.

\section{KESIMPULAN DAN SARAN}

Kesimpulan hasil penelitian ini adalah:

1. Kebijakan dividen (Dividen Payout Ratio) cenderung tinggi, hal tersebut dapat dilihat dari rata-rata dividen yang dibagikan setiap tahunnya di atas 30\%, itu berarti Perusahaan Industri Manufaktur lebih memilih membagikan dividen dibandingkan menahan labanya, dikarenakan perusahaan memilii kas yang cukup besar untuk melakukan ekspansi.

2. Profitabilitas perusahaan mengalami fluktuatif, ketika perusahaan melakukan efisiensi aset, profitabilitas meningkat, begitupun sebaliknya, ketika terdapat inefisiensi aset, profitabilitas cenderung menurun dikarenakan banyaknya aset-aset yang menganggur sehingga tidak mencapai profitabilitas yang optimal.

3. Pertumbuhan aset perusahaan cenderung mengalami penurunan disebabkan adanya efisiensi aset, diantaranya mengurangi transaksi penjualan dalam bentuk kredit serta menjual aset-aset yang tidak produktif.

4. Nilai perusahaan Industri Manufaktur di Bursa Efek Indonesia rata-rata $>1$, artinya bahwa nilai dari perusahaan tersebut di atas harga wajar atau harga normal.

5. Kebijakan Dividen, Profitabilitas, dan Pertumbuhan Perusahaan secara serempak berpengaruh signifikan terhadap Nilai Perusahaan Perusahaan Industri Manufaktur di Bursa Efek Indonesia.

6. Kebijakan Dividen secara parsial berpengaruh negatif dan tidak signifikan terhadap Nilai Perusahaan Perusahaan Industri Manufaktur di Bursa Efek Indonesia.

7. Profitabilitas secara parsial berpengaruh positif dan signifikan terhadap Nilai Perusahaan Perusahaan Industri Manufaktur di Bursa Efek Indonesia.

8. Pertumbuhan Aset Perusahaan secara parsial berpengaruh negatif dan tidak signifikan Nilai Perusahaan Perusahaan Industri Manufaktur di Bursa Efek Indonesia.

Saran dalam penelitian ini adalah:

1. Bagi investor sebaiknya melihat prospek dan kinerja keuangan perusahaan industri manufaktur terlebih dahulu sebelum menanamkan modalnya pada perusahaan tersebut. Meskipun hasil penelitian ini menunjukkan bahwa secara serempak kinerja keuangan (dividen payout ratio, return on asset dan growth) berpengaruh signifikan terhadap nilai perusahaan, namun secara parsial dividen payout ratio, return on asset dan growth tidak berpengaruh signifikan terhadap nilai perusahaan. Hal inilah yang harus diwaspadai oleh para investor dalam berinvestasi. 
2. Untuk pihak perusahaan, diharapkan manajemen dapat menyajikan dengan jelas laporan keuangan perusahaan beserta rasio keuangan secara lengkap dengan harapan agar investor mendapat gambaran terhadap kondisi keuangan dan prospek perusahaan dimasa mendatang.

3. Penelitian ini hanya terbatas pada industri manufaktur dan juga dengan periode yang relatif singkat, maka peneliti selanjutnya dapat mengembangkan hasil penelitian dengan menambahkan sektor industri lainnya sebagai sampel serta memperpanjang periode penelitiannya agar memperoleh hasil yang lebih akurat serta menambahkan variabel lain yang mungkin akan menunjukkan pengaruh lebih terhadap nilai perusahaan.

\section{REFERENSI}

Agus Harjito dan Martono. (2005). Manajemen Keuangan. Yogyakarta: Ekonisia.

Agustina, Silvia. (2013). Pengaruh Profitabilitas dan Pengungkapan Corporate Social Responsibility Terhadap Nilai Perusahaan (Studi Empiris pada Perusahaan Manufaktur yang Terdaftar di Bursa Efek Indonesia). Skripsi. Padang: Universitas Negeri Padang.

Ang, Robert. (2007). Buku Pintar Pasar Modal Indonesia (The Intelligent Guide To Indonesian Capital Market). Edisi Pertama. Jakarta: Mediasoft Indonesia.

Arikunto. (2006). Prosedur Penelitian Suatu Pendekatan Praktik, Ed Revisi VI. Jakarta: Rineka Cipta. Bhaduri, Saumitra N. (2002). Determinants of Corporate Borrowing: Some Evidence from the Indian Corporate Structure, Journal of Economics and Finance, Summer, 26, 2, 200.

Brigham, E. F, dan Joel F. H. 2001. Dasar-Dasar Manajemen Keuangan. Jakarta: Salemba Empat. Brigham, E. F. dan L. C. Gapenski. (1996).Intermediate Financial Management. Fifth Edition, New York: The Dryden Press.

Claessens, S; Djankov, Simeon; Fan, J.P.H.; dan Lang, L.H.P. (2003). Disentagling the Incentive and Entrenchment Effects of Large Shareholdings. Journal of Finance. Vol.57, No.6, 2741-1771.

Euis, S, dan Taswan. (2002). "Pengaruh Kebijakan Hutang Terhadap Nilai Perusahaan Serta Beberapa Faktor Yang Mempengaruhinya”. Jurnal Bisnis dan Ekonomi. STIE STIKUBANK, Semarang.

Helfert, Erich A. (1997). Teknik Analisis Keuangan. Terjemahan, Herman Wibowo. Jakarta: Erlangga. James, C. Horne. (2005). Akuntansi Lanjutan 2. Jakarta: PT. Raja Grafindo.

Keown, A.J. (2004). Manajemen Keuangan: Prinsip-Prinsip dan Aplikasi. Jakarta: PT.Indeks Kelompok Gramedia.

Klapper, L.F., dan I. Love. (2012). Corporate Governance, Investor Protection and Performance in Emerging Markets. World Bank Policy Research Working Paper 2818.

Nachrowi, D,dan Hardius U. (2006). Pendekatan Populer dan Praktis Ekonometrika Untuk Analisis Ekonomi dan Keuangan. Jakarta: Raja Grafindo.

Pakpahan, R. (2010). Pengaruh Faktor-Faktor Fundamental Perusahaan dan Kebijakan Deviden Terhadap Nilai Perusahaan. Jurnal Ekonomi, Keuangan, Perbankan dan Akuntansi, Vol. 2, No. 2, 211-227.

Prihantoro. (2003). Estimasi Pengaruh Dividen Payout Ratio pada Perusahaan Publik di Indonesia. Jurnal Ekonomi dan Bisnis, vol.8, No.1, 7-14.

Saidi. (2004). Faktor-faktor yang mempengaruhi struktur modal pada perusahaan manufaktur GoPublik di BEJ Tahun 1997-2002. Jurnal Bisnis dan Ekonomi, Vol. 11, No.1, 44-58.

Subramanyam, K.R. (1996). The Pricing of Discretionary Accrual. Journal of Accounting and Economics, 22, 249-291.

Sugiyono. (2011). Metode Penelitian Kuantitatif, Kualitatif dan R\&D. Bandung: CV. Alfabeta.

Sugiyono. (2014). Metode Penelitian Bisnis. Bandung: CV. Alfabeta.

Triwahyuni.( 2013). Pengenalan Teknologi Informasi. Yogyakarta: Andi Offset.

Wolk. (2000). Accounting Theory: A Conceptual Institusional Approach. Fifth Edition. South Western College Publishing. 